European journal of American studies

\title{
Constructing a New Regionality: Daphne Marlatt and Writing the West Coast
}

Michelle Hartley

\section{(2) OpenEdition \\ Journals}

Electronic version

URL: https://journals.openedition.org/ejas/10428

DOI: $10.4000 /$ ejas. 10428

ISSN: 1991-9336

Publisher

European Association for American Studies

Electronic reference

Michelle Hartley, "Constructing a New Regionality: Daphne Marlatt and Writing the West Coast", European journal of American studies [Online], 9-3 | 2014, document 8, Online since 23 December 2014 connection on 08 July 2021. URL: http://journals.openedition.org/ejas/10428 ; DOI: https://doi.org/ 10.4000/ejas. 10428

This text was automatically generated on 8 July 2021 .

Creative Commons License 


\title{
Constructing a New Regionality: Daphne Marlatt and Writing the West Coast
}

\author{
Michelle Hartley
}

\section{Introduction}

1 In her long poem Steveston, first published in 1974 and republished in varied form twice more $(1984 ; 2001)$, Daphne Marlatt writes of the village's site at the mouth of the South Arm of the Fraser River in British Columbia: "Washing from east to west, how the river flows, washing its / filth downstream \& silting islands of work men dredge their channels thru, / grassland, sedge. The work it takes to keep men busy" (41). These lines depict an image of landscape familiar to regionalist depictions that stress local work and geography, the confluence of river and men. However, I begin this paper with these lines because the dredged channels and dykes of Steveston offer a metonymy for the kind of denaturalized process of reading region for which I advocate in the following section of this paper, "Regionalism, the West Coast, and Regionality." While traditional regionalism has stressed rural, realist reportage, a type of writing seemingly naively authentic to a landscape, Marlatt's lines stress how one constructs a landscape, stressing human intervention, the dredging of channels and creation of dykes in a continual process of reclamation. Moreover, Marlatt's idiosyncratic orthography (\&, thru) and repeated use of present participles and fragments foregrounds her experimentation with poetic form, emphasizing the creative labor that goes into this process. To help elaborate the connection between regions and language, human geographer Mireya Folch-Serra uses Mikhail Bakhtin's theories to describe how human agency

creates landscapes through metaphors and comparisons whose outcome is the building of roads, towns and cultures. Landscapes, in this light, can be regarded as repositories of polyphony and heteroglossia: places where social, historical and geographical conditions allow different voices to express themselves differently than they would under any other conditions. (255-56) 
2 Thus place becomes not a stable marker of community, industry, and social divisions, but a living repository of voice(s), allowing for the possibility of distancing discussions of region from naturalized and often simplified notions of what constitutes a place and its literature. In this paper I argue for regionality as a term that both addresses the intersection of regions and writing from those regions and avoids the regionalist fallacies of ruralism and realism. In order to trace a more fugitive "regionality," especially one with transnational aesthetic affiliations, I first site Marlatt at that intersection of region and writing: the University of British Columbia's English Department and Poetry initiatives in the early 1960s and the literary archive that has built up around that generation of West Coast writers.

\section{Regionalism, the West Coast, and Regionality}

Since the 1990s Canadian and American studies have witnessed a surge of interest in the local, the regional, the global, and their intersections. Part of the work in renewing literary regionalism as a useful category has involved examining and rejecting regionalism's pejorative synonyms: parochial, banal, insular, and rural. This dismissive language justifies a status quo that equates the "center" (of a country, of mainstream beliefs, of established literary modes) with value. Another part of the work involves expanding the defining characteristics of a regional literary work to include the urban and the experimental. In this essay, I argue for building on regionalism's concern for place, space, and identity, but also for attending to the critiques of regionalisms that label the aesthetic and cultural concerns of these ideologies too narrowly. For example, traditionally discussions of the West Coast as a literary region have been hindered by a prevailing regionalist attention to realism as a primary aesthetic. In On Canadian Poetry (1943), E.K. Brown called for "accuracy, not merely of fact, but accuracy of tone" as the primary criterion for evaluation (23). Regionalist art has often been seen as a lesser and inherently limited art form with mimesis as its only power. Thus, Brown dismisses it: "The advent of regionalism may be welcomed with reservations as a stage through which it may be well for us to pass, as a discipline and a purgation" (24). Since the 1940s, then, regionalist art has been distinguished as parochial rather than cosmopolitan, reportage or local-color writing rather than creative genius, and accordingly deserving of its dismissal as "purgation." Laurie Ricou states that his crossborder approach in The Arbutus/Madrone Files: Reading the Pacific Northwest (2002) results from a West Coast resistance to regionalism: "few if any attempts to define a regional literature within the boundaries of political units have taken strong hold ... [There is] a general reluctance to define" (167). While there is a long list of book-length monographs on Prairie writing both within and across national borders, the criticism of West Coast writing offers a shorter list of essays.i Alison Calder's $1996 \mathrm{PhD}$ dissertation critiques many of these studies for promulgating an unvarying view of the Prairies that ignores its industry, immigration patterns, and variety in landscape. Indeed, she finds that literary regionalism can border on xenophobia when it limits the characteristics of a region to homogeneity. This brand of regionalism's "features," then, becomes a kind of social prescription defining what is and is not acceptable as part of the Prairie. The West Coast has not suffered such homogenizing, but dominant and distinctive strands of its writing have resisted realism, and this resistance has historically made the West Coast unmanageable within the traditional discursive 
structure set out for literary regionalism: a sometimes naive equation drawn between regionalist art, its practitioners, and the land from whence it springs.

"Regionalist" as a descriptor implies, still, both a stylistic and an ideological conservatism, a narrow focus that pays too much attention to place as "setting" and too little attention to the imaginative and aesthetic qualities of writing. Whether due to political or aesthetic conservatism, literary criticism based on such uncontested regionalisms tends to efface difference. It looks for applicable stereotypes of region within writing, rather than attempting to discern what constitutes a region by examining its particularities in literature. As Marlatt's fellow poet and critic Frank Davey notes in "Toward the Ends of Regionalism," change to a regionalism, therefore, "tend[s] to replace one nostalgic mythology with another" (9). iii By contrast, regionality as a guiding principle acknowledges region as a heterogeneous and politicized space, a series of chronotopes, emphasizing the intersection of differing ideologies and standpoints within a region.

\section{A Starting Point: UBC as Archive}

5 Ricou's The Arbutus/Madrone Files demonstrates that West Coast literature requires a methodology that addresses its instabilities. Ricou's choice of various "files" designated by features of West Coast ecosystems for his regional study, rather than a single identity, attests to the productive variability of the region, especially with his addition of "Afterfiles." These "Afterfiles" not only follow the main arguments "a supplementcomplementary," but they are "also, in their relation to the Files, alternate, resistant, approximate" (2), stressing the unfinished. I argue that examining how writers construct regionality-rather than making a "concerted claim for coherence" (167) as Ricou puts it-makes the most sense. Looking at how a writer like Marlatt discovers and re-discovers place and region through her writing and re-writing, from the 1960s into the second decade of the $21^{\text {st }}$ century, offers a focused perspective on what might otherwise be a too diffuse discussion of a transnational region. Therefore, I am most interested in Marlatt's returns to the West Coast, Vancouver, and its suburbs, her multiple versions constructing a vision of place in various times, or chronotopes, reseeing and re-writing when the culture, landscape, or city shifts to reveal another.

My essay examines a web of history, dialogues, and writing, choosing to center on Marlatt as representative of the writing that emerges from the institutional site of the University of British Columbia with its rich archive of recorded poetry events and documented dialogues between poets. ${ }^{\text {iv }}$ The correspondences between literary works, literary history, and the rewriting of historical materiality and ideology can be traced back and forth between creative writers and this region. While avoiding what Bakhtin cautions against in "Forms of Time and Chronotope in the Novel"-namely, a "naive biographism" and a "naive realism" (253-54)-I will argue that the boundary between writer and writing is permeable. According to Bakhtin,

[h] owever forcefully the real and the represented world resist fusion, however immutable the presence of that categorical boundary line between them, they are nevertheless indissolubly tied up with each other and find themselves in continual mutual interaction. (254)

7 Even when literary criticism chooses not to focus on the limited categories of realism and descriptive accuracy, literary regions are constructed through their authors' 
biographical ties to specific places. In using the designation regionality, I also follow Francesco Loriggio's call for regionalism to "invert...one of Bakhtin's neologisms, which both amends and preserves the century's bias in favour of time," to approach regionalism, "topochronically... privileg[ing] space but without disavowing time" (22). Times change places; therefore, mobilizing the theories of Bakhtin both "amends and preserves" the study of literary regionalism by focusing on process, genre, time and space, and their challenges to traditional modes of thought.

\section{Daphne Marlatt's Early Influences: Tish, Locus, Olson}

8 UBC in the 1960s was home to a group of undergraduate writers, including poets, novelists, historians, and literary critics, who later became fundamental to Canadian poetry and its debates: George Bowering, Frank Davey, Fred Wah, Daphne Marlatt, W.H. New, Wayson Choy, and Jack Hodgins were only some of the creative writers and future scholars of Canadian literature at UBC, marking it as a useful nexus point for considering the impact of a cross-border literary regionality. The critical heritage of Bowering, Davey, Wah, and Marlatt begins with Tish, a poetry newsletter instigated by American poet Robert Duncan and produced by Davey, Bowering, and fellow undergraduate and MA students at UBC, who formed an editorial collective and disseminated writing-in-process that reflected aesthetic debates over the American New Poetry." The community's and the newsletter's engagement with aesthetic theories, especially theories manifesting a concern for experiential immediacy rather than realism, and Tish's policy of publishing work-in-progress marked members such as George Bowering and Daphne Marlatt, influencing their next 50 years of writing both critical and creative. In Davey's "Introduction" to the reprinting of Tish issues1-19, he writes that "[t]he impulse to create Tish had been sparked by [American poet] Robert Duncan during three nights of lectures, July 23,24, and 25, 1961" and that "the main push toward a magazine was Duncan's" (3). Tish came at a particular moment, and a particular chronotope emerges in all the writing about it: UBC 1961-1963. That chronotope integrated national differences in contrast to the strain of fervent antiAmerican Canadian nationalism that followed Canada's 1967 centennial to be found in critical works such as Keith Richardson's Poetry and the Colonized Mind: Tish (1976). By contrast, Davey notes in The Writing Life that while the Tish poets were heavily influenced by American poet Charles Olson and encouraged to begin this publishing venture by Duncan, Olson's teachings led the UBC students to write out of their own moment and place, not out of an "American" ethos or a timeless ahistorical geographical region:

Far from encouraging imitative writings, Olson's poetic insists upon each writer's manifesting himself in language exactly appropriate to the person he is and to the physical and temporal circumstances in which he writes. This poetic, accurately followed, precludes the possibility of the kind of colonialist writing which [Robin] Matthews and [Milton] Acorn pretend to have been Tish's goal. (17)

9 I would argue that Tish marks the beginning of a transnational aesthetic of regionality, written by Canadians in dialogue with American poets, to interrogate and construct the local Vancouver scene in writing. ${ }^{\mathrm{vi}}$ 
10 While the concepts of space, place, and subjectivity that emerged from Tish were influenced by Olson's situational poetics, the resulting poetry and poetic theory emerges from local ground or, to use the word coming out of the Tish chronotope, "locus." "Locus" is a word that means place but also signals certain philosophical and aesthetic inclinations. While its specific etymological history in contemporary poetics is difficult to track, for postmodern American poets like Duncan, Creeley, and Olson, it signifies a writer's insistence on the "physical and temporal circumstance," as Davey puts it ("Introduction" 17). In an interview with Caroline Bayard, Tish editor Bowering has stated:

The word that we used all the time was "locus," which we liked partly because it came out of Olson, partly because it didn't say setting, it didn't say place, it didn't say landscape, it didn't say all those things that are literary devices. Every time you use one of those terms you posit a person who is saying, OK, now how can I organize all this into a literary work. But if you said locus, it implies trying to find out where you are. (Bayard and David 79-80)

11 Examining this influence as part of a transnational regionality seems more productive than the more exclusive rhetoric of the nationalist and regionalist literary criticism of the 1970s and 1980s, especially as the influence of Duncan, Olson, and Creeley resulted in writing that emphasized the nuances of the local for Vancouver writers, and the energy of the Vancouver Poetry Conference motivated the ensuing Poetry Conference at Berkeley in 1965. Olson used the term "locus" rarely in his published writings, but it is important to his conception of "History as events": "I think the best thing is to have yourself catch [history] up as you have to, (a) because so few even good men will bother with it; and (b) the sequence of events you will want for yourself-just as you want geography: the locus is now both place \& time (typology)" ("Bibliography" 308). Olson's dictum stresses the importance of rethinking time and space in ways that are congruent with what I call regionality.

Daphne Marlatt's diverse output provides evidence of a lifetime of engaging the history and geography of the West Coast in her published process poetics, beginning with Vancouver Poems (1972), the re-issue of some of those poems in What Matters: Writing 1968-1970 (1980), and rewriting the sequence entirely in Liquidities: Vancouver Poems Then and Now (2013). Brenda Carr's theorization of the "Steveston spiral" offers a cogent spatial trope for another of Marlatt's ongoing projects, which has now extended over 25 years with the 2006 dramatic production of a Noh play set in Steveston, "The Gull," and its subsequent publication in 2009:

[The Steveston spiral] evolves from the uncollected little magazine poem sequence, "Steveston. Support? Fish." (1973), to the first edition of her well-known long poem/photography collection with Robert Minden (Steveston 1974), to the aural history documentary edited by Marlatt (Steveston Recollected 1975), to the documentary radio play commissioned by and aired on the CBC (One Life. Steveston 1976), to the inclusion of the text without photographs in Michael Ondaatje's The Long Poem Anthology (1979), to the reorganized edition, with photographic additions, of the Minden collaboration (1984). (102-3)

13 The project also includes Salvage (1991), the third edition of Steveston published by Ronsdale Press in 2001, and the performance of its poems as soundscapes with previous collaborator Robert Minden. In a third project, Marlatt's novels Ana Historic (1988), Taken (1996), and the long poem The Given (2008) all demonstrate the intersection of Marlatt's writing life, Vancouver's history, and autobiography. In the following sections, I will examine a few examples from the Vancouver Poems project and Steveston. 


\section{Vancouver Poems} her attempt to "locate herself" occurs through her relation to the histories of the disparate populations that make up Vancouver's cultural and social geography, as well as its myths and mountains. Marlatt's early work shares the current concerns of Vancouver-based critics such as Rita Wong, Glen Lowry, and Roy Miki to poetically publicize issues of racism, poverty, and classism on the West Coast. Vancouver Poems (1972) and Steveston (1974) demonstrate that historical disparities are integral to her reading of the city's layers, her place in it, and both the poet's and the city's place in the world. In both works Vancouver takes on a "strangeness" in the poems due to Marlatt's perception of it from an immigrant's perspective. vii Marlatt explains in an interview with George Bowering that she perceives poetic form working to represent a process of moving through the city: "the line itself is a walking down a street; it's that step-by-step, perception-by-perception thing. But as you continue to walk down it you get a sense of the character of that street" (Bowering, "Given" 69). viii The journey is complicated because simultaneous to this phenomenological, horizontal movement, Marlatt enacts a historical, what she terms "vertical," movement that reflects her digging into the city's archives:

It's as if I was drilling, like thru the present, \& the immediate present was the people that I knew; down from that into a larger collective present, which was the streets, the city, things I was seeing on the streets, like the English Bay poem; down deeper into, quote, history, the fire \& so on; deeper still, prehistory, which was before the written records that we keep, native Indian. (72)

This drilling follows from Olson's urging: "Best thing to do is to dig one thing or place or man until you yourself know more abt [sic] that than is possible to any other man. It doesn't matter whether it's Barbed Wire or Pemmican or Paterson or Iowa. But exhaust it. Saturate it. Beat it" ("Bibliography" 306-7). In addition to recording her own personal peregrinations through a contemporary city, Marlatt digs into Vancouver and the West Coast by going through the archive at the Vancouver Public Library and examining Vancouver history in Vancouver Poems. She also recovers voices and stories through oral recordings, another form of digging in Steveston. Her various returns from Salvage (1991) to Liquidities: Vancouver Poems Then and Now (2013), in turn, add to the region's creative archive, as Marlatt constructs versions of the coast through her writings, rewriting her earlier work with changes in time, space, and perspective. In her introduction to Liquidities, she writes about her need to rewrite rather than simply re-issue the poems. As the locus changes, even the term resonates with the 1960 s and 1970s, the aesthetic and poems refract those changes:

Vancouver's incessant deconstruction and reconstruction, its quick transformations both in (re)structured ground and in urban imagining, come further into play in the new series of poems, Liquidities (from liquid assets, cash and increasingly from the incessant rain of global warming). The slower, more introspective rhythms of the city poems some forty years ago speed up as wordplay, faster image traffic, quicker jumps through milieu and temporal strata that intensify verbal collisions in the new poems. (xii)

Marlatt's works from the region from the 1960 s to the $21^{\text {st }}$ century and her revisitings enable a focused discussion of the changes. Marlatt's "walk" in her early work from the diary entries archived in What Matters: Writing 1968-1970, Vancouver Poems, and Steveston 
uses her own position as an immigrant to delineate Vancouver and its environs as a region of immigrants and outsiders who come to belong to a place by constructing relationships with it, rather than being born to it.

Vancouver Poems, as Marlatt notes in an 1974 interview with Bowering, is a sequence that results from Marlatt writing her way through "the roots of the city" (Marlatt, What Matters 74). In these poems she develops her poetic technique toward the long line that she will establish fully in Steveston, and she also moves into using historical research as "matter" for her poetry, representing Vancouver as a specifically immigrant city in the process.In its use of quotations and details from newspaper clippings in the Vancouver archives, "ix "who could know" from Vancouver Poems gives readers the scene and sense of what the city's structure has been built upon, namely, its connection to trade, Empire, and the alienated labour of working, usually racialized, bodies:

VIADUCT:

'several transcontinental trains daily' underfoot.

At foot, sea. 'CPR's 14-ship coastal fleet... (or) regular

calls of white Empresses from the Orient.'

principally a

passenger embarcation, for, he remarked, with pride, the

metropolis. Thought, high-buttoned, boots a stamp of

that civility, the Lions ranging, royalty on a cowcatcher

(snicker) view the Rockies, O Empire. Furthest outpost

cradled inland sea the ships go down to, \& they

crowded round as so many shadows view the new

arrivals (Vancouver Poems [21]; also in Net Work 45)

The "VIADUCT" is a conduit for trade. Marlatt capitalizes every letter in this repetition of the word; through eye slip it becomes a secondary but emphatic title in opposition to the title that doubles as the poem's opening clause, "who could know." "VIADUCT" stresses the movement of people and goods through the city. The "passenger embarcation" with its flow of bodies adds money to the system, as do the labour bodies of the "terrific / coolie movements" (45), but the movements of raced migrants rather than tourists are a source of anxiety within the immigrant city almost from its inception, as Marlatt indicates through her inclusion of historical events from 1887 to her poem's present, 1968. The poem moves from the Pier D Fire that destroyed one of the links between the CPR's trains and its ships of the line in 1938 back to the celebratory "London 29 days out of Yokohama," referencing the SS Abyssinia's journey to Vancouver in 1887. Thus Marlatt understands Vancouver as a trade gateway because of its birth as a cosmopolitan "metropolis" and its place in the empire along the Yokohama-Vancouver-New York-London passage. Indeed, Marlatt reveals her awareness of what Empire has always entailed-trade, division, and conflict. Vancouver was always a transnational region, a transit point in a network of relations that allowed goods and people to flow across borders. Marlatt's rewriting emphasizes the movement of labor, juxtapositioned more carefully against Vancouver geography: "Lions chasmic yawning" stresses the iconic mountains of the West Coast and the potential for labor to be lost in a global abyss.

19 The connection between trains and ships suggested by the viaduct, a word which etymologically relates to finding a "way through" or "past," also suggests that the city is most important as a transitional site for transit links and transient populations of workers moving to other parts of the nation and empire. Passenger ships and trains carry commodities like the expensive orchids mentioned in the poem's first 
incarnation or the tea and silk in the second, commodities that are "heavily insured" (What Matters 45), but lives seem less valuable to the colonial societies that Marlatt uncovered in Vancouver's document repository. Marlatt includes pieces of history, and the poetic lines move via connection of word, thought, and image, moving between times to focus on the site of the city and its shifting contradictions. The connection between the past and future of Vancouver and Marlatt's writings and rewritings of the poems continues to be immigrant alienation. It is the poem's speaker who cries "wait..." amid this flood of activity in a "boomtown," using the held moment of the ellipsis trailing off to bring up more history, more layers of the past into the site of the city and the poem.

\section{Steveston}

The notion of the boomtown seems to have piqued Marlatt's poetic and historic curiosity. The history of the West Coast, and of British Columbia generally, is a history of the boomtown: settlements that rise and fall with single resource industries like fur, gold, lumber, or fish. Geographer Cole Harris describes North America's West Coast as a new human geography based on the collision of resources and modern systems of capitalist extraction, but the intersections of global corporations mark the place and people too:

As British Columbian resources came within range, capital poured in, often building the systems of transportation and communication it required....In this, rather than in pioneer agriculture, was the principal momentum of settlement and economic growth in an emerging immigrant British Columbia. (257)

Before Canada's West Coast became part of a nation or province, it was a transnational region subject to the vagaries of globalized capitalism not only through the ships in port but also through regional resource industries. "[C]apital pour[s] in," as Harris suggests, but also quickly dissipates. Steveston, the town where Marlatt turned her archival/poetic intelligence in the early 1970s, was the "salmon capital of the World" in the late $19^{\text {th }}$ century, a waning fishing village about to be swallowed by Vancouver's suburban sprawl in the 1970s, a tourist destination with a cannery museum in the $21^{\text {st }}$ century.

Steveston exhibits Olson's influence at numerous points. Beyond her attempt to "dig" into this one place and every aspect of it, Marlatt again engages Olson's dictum to stress perception moment by moment. In “'Against the Source': Daphne Marlatt's Revision of Charles Olson," Sabrina Reed documents the parallels between Steveston and Olson's Maximus poems (1960), focused on Gloucester, Massachusetts; both poets "establish themselves as centres of consciousness whose movements through their respective locales allow them to comment on the lives and histories they encounter" (133). Both locales are fishing villages facing the rising regional tension with "corporate interests," in Steveston's case a real estate conglomerate. Reed argues that the difference between the two poets lies in their understanding of individuality, and how individuality was for Marlatt ineluctably attached to gender in the 1960s and 1970s. Olson perceived himself linked with the universal, but even in the 1970s before her later work with French feminism and attempts at lesbian utterance in Ana Historic (1988), Marlatt emphasizes the unsuitability of Olson's poetic "sprawl" for her project. Reading backward from the feminist rewriting of Steveston in Salvage, reading Steveston through Salvage, as it were, it 
is possible to foresee Marlatt pushing the gendered boundaries of 1970s society in her focus on the female fisherman, Inez, and her resistance to the Japanese-Canadian fishermen sexualizing the "Hippie" woman poet (38).

Marlatt also focuses on the Native presence in her vision of Vancouver's past and present in a way that Olson does not. Reed notes:

[Olson] views the history of migration from the perspective of the Greco-Roman/ European tradition, and thus the term "manifest destiny" does not seem out of place. Olson's celebration of the colonization of Gloucester largely ignores the displacement of Native peoples or even the slaves who made a slightly later forced migration to the 'New' World. (143n2)

By contrast, Marlatt's own immigrant past and her interest in the intersecting demands of various demographics on the West Coast construct an immigrant city built on Native land both in Vancouver Poems and Steveston. " Accumulation," one of Marlatt's tropes in Steveston, and traceable in her larger body of work, occurs not only in the layers of soil on the delta, but also in the form of her own accumulated observations. She uses the trope to positively construct a sense of belonging, to build connections to communities: Steveston's fishermen, Vancouver's poets, etc. She also reads it negatively when corporatization takes over from that community in the form of accumulating

deposits (in a bank, in the Richmond

Credit Union, in shares in BC Packers, in) a town whose main street moves, as Manoah did, from Moncton New Brunswick, west, in a vision of telephone poles, wires, cement. A straight line from east to west, from farm at its eastern end, to Steveston Hotel, knife in teeth, Canada Fish.

Shadowy, this,

piratical emblem of another era. Boomtown. Dream of seizing silver wealth that swims, \& fixing it in solid ground, land, home. A mis-reading of the river's push. (Steveston 42)

Accumulation, fish, nets, backwater, and boomtown provide the poem's iterative structure, and evidence of Marlatt's Olsonian "digging" in the community's experience. The web of nets provides a physical reminder of the community's labor in fishing the shoals, stringing nets across the mouths of sloughs to catch the fish. In addition, Marlatt's poetic points out that the fishermen and women are also caught: in dreams of "silvery wealth" that are "[a] mis-reading of the river's push" (42). On the delta, roots go into the river as well as the soil, reinforcing the constructed nature of claims to being rooted in a ground or in the soil. The soil on the delta must be reclaimed and protected by dykes; a sense of belonging to a place or a region must be built, re-built, and produced by claims of affinity or by writing and re-writing, as Marlatt does.

In Steveston, rather than being a conduit for movement beyond the boundaries of a "backwater," the street is part of a community that accumulates bodies and their stories over time. It has depth. The delta accumulates silt and ground over the years - "Islands of it moving west, 1000 feet per century"-and the settlement acquires people, streets, a past. There becomes "here":

The edge, the edge. Settled by it. Camped rather. Cluster of

fishing shacks temporary as those Japanese who slept on boats arriving, each

season, for the fish, to stay, stray into settlement, believing they were

only here this year, sending money home \& staying on to the next, \& the next...

(Steveston 41-42)

The temporary camps and sojourners become "long-term residents" and, like many other towns in the region along the coast, create hierarchies to discipline their 
disparate populations. Different races are allocated different jobs, and the Native Canadians are deracinated, uprooted from their rightful grounds, but employed:

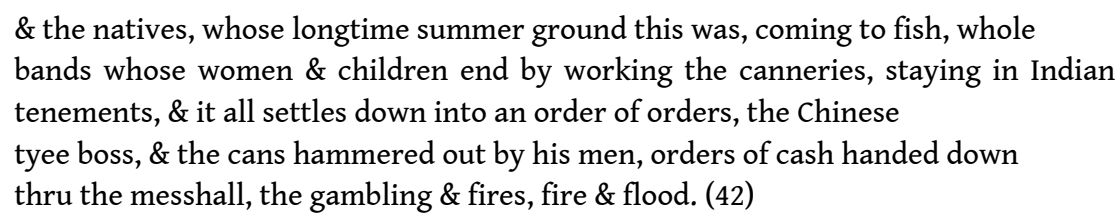

Marlatt's long lines offer history through experiences, processing the latter in a fashion dictated by B.C.'s racial ideology with "sharp boundaries" (Harris 270) and discrete places. But unlike earlier B.C. histories such as G.W. Taylor's Timber: History of the Forest Industry in B.C. (1975), Marlatt focuses on these workers in her poem and not on the profits their work brings. ${ }^{x i}$ She hears the stories from the repository of documents in the Vancouver archives, the polyphonic repository of voices that the Steveston residents allow her to access through their oral stories, and her poems and rewritings allow readers to witness how the work changes the landscape. To return to Folch-Serra, "[1]andscapes, in this light, can be regarded as repositories of polyphony and heteroglossia: places where social, historical and geographical conditions allow different voices to express themselves differently than they would under any other conditions" (255-56), even when the landscape contains the ruins of three separate bunkhouses for three different sets of workers. The boom required Chinese, Japanese, and Native workers to fulfill the companies' "orders" until technology could replace most of them and industrial efficiency depleted the fish stocks:

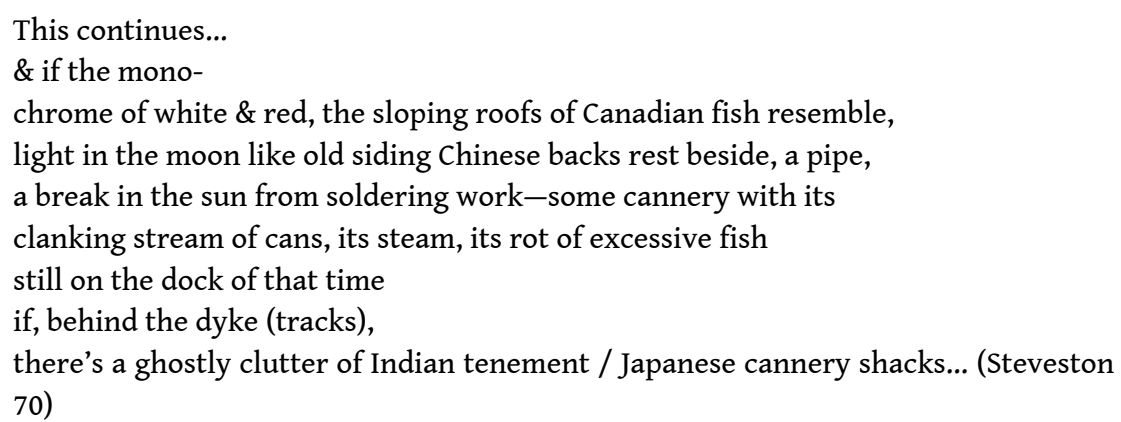

Marlatt's reading and rewriting of Steveston in her long poem "foreground[s] the materiality of language" (Kamboureli 102) by stressing the material consequences of linguistic acts.

Marlatt's use of an ephemeral document, the sign on a closed post office, provides one example of this inextricable link between language and materiality: the enunciation of a post office's closing rewrites the "boomtown" as "backwater" and then "suburb." Poems such as "How it goes" tell of a town's passing:

How it goes

Men sleeping, lives, or lives sleeping, doors. On Moncton, in the

store window, a pall draped placard reads:

In Memoriam

Steveston Post Office

Doors closed

May 13th 1972 (Steveston 28)

31 The placard performs the work of mourning for a community that is itself becoming absent. With the removal of the post office, the fishing village as it was passes into memory; Marlatt's poem, with its use of the present tense, enacts her awareness of what that passing signifies: the closing of doors, the bust that follows the boom. In her 
poem, Marlatt attempts to replicate the living presence of the town even as she mourns its passing. Moreover, Marlatt's mourning, as observer, makes it clear that Steveston's loss is common in the region, which is represented by "housing development, each internal room focused on a further internal / screen, whose smaller \& smaller ponds of thought these 'channels' bring" (22). The generic suburb-iconically linked to the individualized viewing of the television screen with its two-dimensional view and twelve channels-divorces this community that once depended on its inhabitants' knowledge of the water, tides, and channels from its geography, from its time and space. Ricou asserts that "[t]he place names in Marlatt's poem are truly vernacular: they are names spoken by people engaged in the same work, rather than names recorded in public documents. The parenthetic definition of Woodward landing, '(where the ferry ran),' confirms this oral local history" (Arbutus/Madrone 32). Experiential knowledge not placed in any archive.

Without names and phenomenological knowing the landscape changes-what was once a variety of dykes, headlands, channels, and passages used for particular processes becomes a seemingly featureless landscape when the observer cannot differentiate one break from another. Time and place are vital, as is an awareness of the impact of institutions, economic or educational, on the poet and landscape. What Ricou identifies as "oral mapping," a litany of names-Roberts Bank, Albion Dyke, Woodward Reach, Woodward Landing, Woodward Slough, Gravesend Reach, City Reach-a past recorded in Marlatt's poem (Steveston 15), turns at the poem's end to a vision of suburbanization. The only place name comes from the suburb itself, Richmond:

no hand skims now, closing in on this life, this, or this, foreclosed at dusk now, opening the door he wanders out to sit, leaning his chair against the wall \& contemplating closedup house boards, a weltering mattress or the few remaining cards: as visages, his vision is accretion uncountable (is he? accountable) or facing mountains he can't see, wires, $\&$ the roar of Richmond skyline (money), only the falsefront silhouette 'west' is occupies his mind. (18)

The images here stress the accumulation of money or property, not knowledge of place. " "[W]est"' is a shadow of a former self, a "falsefront silhouette," a phrase that seems to imagine progress without accountability. The passing of the town into a suburb -"Richmond skyline (money)"-is not a natural consequence of time or geography but a direct consequence of corporate interests and actions. Marlatt immerses herself in the town to read its connections to everyday life, to somehow retain its practice, even as she writes a historical poem about the end of an era. Steveston in this view is both an individual locale and emblematic of the West Coast's regional history of canning towns, exploitation of labor, and cross-cultural interaction. Thus, rather than returning to a regionalist figuring of landscape as determining literary production, Steveston represents regionality itself.

\section{Concluding Thoughts}

Marlatt and Steveston's residents "interlocate" (as Bakhtin would put it) each other reciprocally; xii but Marlatt also interlocates the writers, Canadian and American, who helped her to construct her transnational poetic, a poetic that in turn offers evidence of a new understanding of region: a West Coast regionality constructed through accretion and accumulation, debate, writing and rewriting, and the materiality of time. 
One version overlays another, and the "sub-versions" in fact subvert any totalizing vision. Regionality suggests that the "region" itself is in a continual process of becoming, that any sense of belonging to place is provisional as that place too is provisional, in process, not entirely geographically determined by mountain ranges, oceans, or fjords, but affected by geography, history, immigration, institutions, and idiosyncrasies. Thus, the region is constantly being defined and redefined as writers write and re-write, with new work changing both the writers and the region in the process. In Bakhtin's terms, the entire project is unfinalizable, not unproductive, the defining factors of the region somewhat fluid.

In more pragmatic but comparable terms, human geographer Doreen Massey writes,

[space] is the product of the intricacies and the complexities, the interlockings and the non-interlockings of relations from the unimaginably cosmic to the intimately tiny. And precisely because it is the product of relations, relations which are active practices, material and embedded, practices which have to be carried out, space is always in a process of becoming. It is always being made. (293)

So, too, is region, and therefore it is productive to examine the writers who acknowledge that becoming, include it in their poetic, and respond poetically when they have again to write their way into an understanding of that new space "being made." In Steveston, Marlatt writes "multiplicity simply there: the physical matter of / the place (what matters) meaning, don't get theoretical now, the cannery" (23), but multiplicity is rarely simple, and theorizing a new way of articulating the multiple connections between space and time, region and writing, regionalism and poetics matters.

\section{BIBLIOGRAPHY}

Bakhtin, Mikhail M. The Dialogic Imagination: Four Essays by M.M. Bakhtin. Ed. Michael Holquist. Trans. Caryl Emerson and Michael Holquist. Austin: U of Texas P, 1981.Print.

Bayard, Caroline, and Jack David. "George Bowering." Out-Posts: Interviews, Poetry, Bibliographies and a Critical Introduction to Eight Major Modern Poets. Erin: Porcépic, 1978. 77-99. Print.

Bowering, George. "Given This Body: An Interview with Daphne Marlatt." Open Letter 4.3 (1979): 32-88. Print.

-. "Home Away: A Thematic Study of Some British Columbia Novels." BC Studies 62 (1984): 9-28. Print.

Brown, E.K. On Canadian Poetry. Toronto: McGraw-Hill, 1943. Print.

Calder, Alison. "The Lie of the Land: Regionalism, Environmental Determinism, and the Criticism of Canadian Prairie Writing." Diss. U of Western Ontario. 1996.

Carr, Brenda. "Daphne Marlatt's Salmon Texts: Swimming/Jumping the Margins/Barriers." Diss. U of Western Ontario. 1989. 
Cooley, Dennis. "Three Recent Tish Items: Rev. of Frank Davey, Tish No. 1-19; C.H. Gervais, The Writing Life: Historical \& Critical Views of the Tish Movement; and Keith Richardson, Poetry and the Colonized Mind:Tish." Canadian Poetry 3 (1978): 98. Print.

Davey, Frank. "Introduction.” The Writing Life: Historical \& Critical Views of the Tish Movement, by C.H. Gervais. Coatsworth: Black Moss, 1976. 117-27. Print.

-. "Toward the Ends of Regionalism." A Sense of Place: Re-Evaluating Regionalism in Canadian and American Writing. Ed. Christian Riegel and Herb Wyile. Edmonton: U of Alberta P, 1998. 1-18. Print.

Fairbanks, Carol. Prairie Women: Images in American and Canadian Fiction. New Haven: Yale UP, 1986. Print.

Folch-Serra, M. “Place, Voice, Space: Mikhail Bakhtin's Dialogical Landscape.” Environment and Planning D: Society and Space 8 (1990): 255-74. Print.

Harris, Cole. The Resettlement of British Columbia: Essays on Colonialism and Geographical Change. Vancouver: UBC P, 1997. Print.

Harrison, Dick. Unnamed Country: The Struggle for a Canadian Prairie Fiction. Edmonton: U of Alberta P, 1977. Print.

Holquist, Michael. "Introduction: The Architectonics of Answerability." Art and Answerability: Early Philosophical Essays by M.M. Bakhtin. Ed. M. Holquist and Vadim Liapunov. Trans. Vadim Liapunov. Austin: U of Texas P, 1990. ix-xlix. Print.

Kamboureli, Smaro. On the Edge of Genre: The Contemporary Canadian Long Poem. Toronto: U of Toronto P, 1991. Print.

Kreisel, Henry. "The Prairie: A State of Mind." Trace: Prairie Writers on Writing. Ed. Birk Sproxton. Winnipeg: Turnstone, 1986 [1968]. Print.

Loriggio, Francesco. "Regionalism and Theory." Regionalism Reconsidered: New Approaches to the Field. Ed. David Jordan. New York: Garland, 1994. 3-28. Print.

Mandel, Eli. Another Time. Erin: Porcépic, 1977. Print.

Marlatt, Daphne. Ana Historic. Toronto: Anansi, 1988. Print.

-. The Given. Toronto: McClelland and Stewart, 2008. Print.

-. The Gull. With a Japanese Translation by Toyoshi Yoshihara. Vancouver: Talonbooks, 2009. Print.

-. Liquidities: Vancouver Poems Then and Now. Vancouver: Talonbooks, 2013. Print.

-. Net Work: Selected Writing/Daphne Marlatt. Ed. Fred Wah. Vancouver: Talonbooks, 1980. Print.

-. Salvage. Red Deer: Red Deer College P, 1991. Print.

-. Steveston. $2^{\text {nd }}$ ed. Edmonton: Longspoon, 1984. Print.

-, ed. Steveston Recollected: A Japanese-Canadian History. Victoria: Aural History, Provincial Archives of British Columbia, 1975. Print.

-. Taken. Concord: Anansi, 1996. Print.

-. Vancouver Poems. Toronto: Coach House, 1972. Print.

-. What Matters: Writing 1968-70. Toronto: Coach House, 1980. Print.

Massey, Doreen. "Spaces of Politics." Human Geography Today. Ed. Doreen Massey, John Allen, and Philip Sarre. Cambridge: Polity, 1999. 279-94. Print. 
McCourt, Edward A. The Canadian West in Fiction. Toronto: Ryerson, 1949. Print.

New, W.H. "A Piece of the Continent, A Part of the Main: Some Comments on B.C. Literature." BC Studies 67 (1985): 3-28. Print.

Olson, Charles. “A Bibliography on America for Ed Dorn." Collected Prose: Charles Olson. Ed. Donald Allen and Benjamin Friedlander. Berkeley: U of California P, 1997 [1964]. 297-310. Print.

-. Selected Letters. Ed. Ralph Maud. Berkeley: U of California P, 2000. Print.

Ormsby, Margaret. British Columbia: A History. Toronto: Macmillan,1958. Print.

Pritchard, Allan. “The Shapes of History in British Columbia Writing.” BC Studies 93 (1992): 48-69. Print.

Quantic, Diane Dufva. The Nature of the Place: A Study of Great Plains Fiction. Lincoln: U of Nebraska P, 1995. Print.

Reed, Sabrina. “'Against the Source': Daphne Marlatt's Revision of Charles Olson.” Studies in Canadian Literature 26.1 (2001): 132-44. Print.

Richardson, Keith. Poetry and the Colonized Mind: Tish. Oakville: Mosaic, 1976. Print.

Ricou, Laurie. The Arbutus/Madrone Files: Reading the Pacific Northwest. Corvallis: Oregon State UP, 2002.Print.

-. Vertical Man/Horizontal World: Man and Landscape in Canadian Prairie Fiction. Vancouver: U of British Columbia P, 1973. Print.

-. "The Writing of British Columbia Writing." BC Studies 100 (1993): 106-20. Print.

Taylor, G.W. Timber: History of the Forest Industry in B.C. Vancouver: J.J. Douglas, 1975. Print.

Thacker, Robert. The Great Prairie Fact and Literary Imagination. Albuquerque: U of New Mexico P, 1989. Print.

Wah, Fred, ed. Net Work: Selected Writing/Daphne Marlatt. Vancouver: Talonbooks, 1980. Print.

Woodcock, George. “The Wild Woman: Notes on West Coast Writing.” BC Studies 73 (1987): 3-13. Print.

\section{NOTES}

i. This summation is not as dated as it might seem, although the attitude is contested. During that odd combination of Reality-Radio competition and Canadian belles-lettres, Canada Reads, in 2005, I heard panelist Olivia Chow dismiss one text, Rockbound, as "regionalist" and therefore unworthy of much discussion. It won the contest, nevertheless, perhaps reflecting regionalism's new lease on critical life.

ii. After early forerunner Edward McCourt (The Canadian West in Fiction [1949]) comes a long line of regional studies of Prairie literature like Ricou's Vertical Man/Horizontal World (1973), Eli Mandel's Another Time (1977), Dick Harrison's Unnamed Country: The Struggle for a Canadian Prairie Fiction (1977), Robert Thacker's The Great Prairie Fact and Literary Imagination (1989), Carol Fairbanks's Prairie Women: Images in American and Canadian Fiction (1986), Diane Quantic's The Nature of the Place: A Study of Great Plains Fiction (1995), and the recent turn to transnational and border regions have engendered more. By contrast, most of the articles on B.C. literature, George Bowering's "Home Away: A Thematic Study of Some British Columbia Novels" (1984), Allan Pritchard's "The Shapes of History in British Columbia Writing" (1992), W.H. New's “A Piece of 
the Continent, A Part of the Main: Some Comments on B.C. Literature" (1985), George Woodcock's "The Wild Woman: Notes on West Coast Writing" (1987), and Laurie Ricou's overview of them all, “The Writing of British Columbia Writing" (1993), appear in a single journal, BC Studies.

iii. Alternating, for example, Henry Kreisel's "Man, the giant-conqueror, and man, the insignificant dwarf always threatened by defeat" (256) with Ricou's "vertical man" in his horizontal world in Prairie regionalism.

iv. From 1959 to the mid-1960s, UBC was a meeting ground for poets and poetics; moreover, those ephemeral meetings were recorded on audio tapes by then student Fred Wah; in interviews with poets, panelists, and students; later reworked in autobiographical fictions, etc. The holdings at Simon Fraser University, B.C. have not only the recordings but also original posters from the events.

v. See Olson's letters about the American New Poetry, especially the one to the editor, Donald Allen (Letters 273-77).

vi. Dennis Cooley's review, “Three Recent Tish Items," supports Davey's contention and rejects Richardson's overwrought nationalism as early as the late 1970s. He writes,

Tish poetry is proudly West Coast. Olson, chief theoretician for the editors of that magazine, insisted that poets must write in their own unique voices out of their own particular places, "foolishly 'local,' heavy with particulars," as he recommends. No other places and no other voices-certainly not Olson's world and Olson's voice-would do. Be in Vancouver, of Vancouver-here, now (in 1962)-that is what Olson said to Lionel Kearns and Daphne Buckle [later Marlatt], David Dawson, Jamie Reid and David Cull, and all the others. It's you and your world that go into your poetry. Writing out of Olson's poetics, then, means anything but imitating his particular form of writing. (98)

vii. Daphne Marlatt was born in Perth, Australia, spending her childhood in Penang, Malaysia until she immigrated with her family to North Vancouver, British Columbia in 1951 at the age of nine.

viii. I am indebted to Fred Wah for picking up on this important explanation of Marlatt's poetic in his introduction to Net Work (1980).

ix. See Bowering, "Given This Body" 70.

x. In the first poem, "wet fur wavers" she writes in its second stanza,

Changes air now wet as the sea, the sh'te

Comes walking up through humor in the way of

Vision, salt. Cedar all over. Cedar for headdress.

Beaver or bear, what is there to the touch of,

you said. Come well back into view. (Liquidities 5)

This version of the poem includes the Japanese word for ghost, sh'te, edited out of the original. With its inclusion Marlatt notes the changing character not only of the city, which is far more inclusive, but that of her poetic, too: her Japanese Noh influences side-by-side with Charles Olson's dictum to dig the one place.

xi. Moreover, unlike Timber, where Native peoples are dismissed after the first two chapters, or Margaret Ormsby's more sympathetic effort, British Columbia: A History (1958), which severely limits discussion of Native peoples, Marlatt's Steveston is more inclusive.

xii. Michael Holquist writes in his introduction to "Art and Answerability":

We not only interrogate each other, we interlocate each other, and it is the interlocative or dialogic self that is the subject of Bakhtin's architectonics. The interlocative self is one that can change places with another-that must, in fact, change places to see where it is. A logical implication of the fact that I can see things you cannot, and you can see things that I cannot, is that our excess of seeing is defined by a lack of seeing: my excess is your lack, and vice versa. If we wish to overcome this lack, 
we try to see what is there together. We must share each other's excess in order to overcome our mutual lack. (xxvi)

\section{ABSTRACTS}

This paper argues for "regionality" as a new term to address the intersection of geographical regions and writing from those regions. The limited applicability of traditionally conceived regionalism to the poetry of the Canadian West Coast demonstrates the need for this new term. The suffix "-ity" stands not for a faith in region or region as totality, but "an instance" or "a degree of" region. These "instances" accrue a processual and multiple version of region. Building on the idea of landscape as repository, this article briefly outlines the importance of institutions (the University of British Columbia's English Department and Poetry Conference in the early 1960s in particular) and literary archives for this methodology. In order to trace a more fugitive regionality, especially one with transnational aesthetic affiliations, one must be able to locate a writer/work among a constellation of documented influences and documented perspectives. This article then argues that Daphne Marlatt's work from the 1970s to 2013 offers a particularly compelling example of how theorizing regionality can open up perception of regions and the writing that emerges from them.

\section{INDEX}

Keywords: American New Poetry, British Columbia, Canadian literature, Daphne Marlatt, Regionalism

\section{AUTHOR}

\section{MICHELLE HARTLEY}

University of Western Ontario 